\title{
Bio-based nanocomposite coating to preserve quality of Fior di latte cheese
}

\author{
D. Gammariello, ${ }^{*}$ A. Conte, ${ }^{*} \dagger$ G. G. Buonocore, $\neq$ and M. A. Del Nobile ${ }^{*}{ }^{1}$ \\ ${ }^{*}$ Food Quality and Health Research Center (BIOAGROMED), University of Foggia, Via Napoli, 25-71122 Foggia, Italy \\ †Department of Food Science, Agricultural Faculty, University of Foggia, Via Napoli, 25-71122 Foggia, Italy \\ ‡Institute for Composites and Biomedical Materials, NRC, P.le Enrico Fermi 1-80055 Portici (Naples), Italy
}

\begin{abstract}
The aim of this study was to evaluate the effects of a bio-based coating containing silver-montmorillonite nanoparticles combined with modified-atmosphere packaging (MAP) on microbial and sensory quality decay of Fior di latte cheese. Different concentrations of silver nanoparticles $(0.25,0.50$, and $1.00 \mathrm{mg} / \mathrm{mL})$ were dispersed in a sodium alginic acid solution $(8 \% \mathrm{wt} / \mathrm{vol})$ before coating the cheese. Modified-atmosphere packaging was made up of $30 \% \mathrm{CO}_{2}, 5 \% \mathrm{O}_{2}$, and $65 \% \mathrm{~N}_{2}$. The combination of silver-based nanocomposite coating and MAP enhanced Fior di latte cheese shelf life. In particular, product stored in the traditional packaging showed a shelf life of about $3 \mathrm{~d}$, whereas coated cheese stored under MAP reached a shelf life of more than $5 \mathrm{~d}$, regardless of the concentration of silver nanoparticles. The synergistic effects between antimicrobial nanoparticles and initial headspace conditions in the package could allow diffusion of dairy products beyond the local area.
\end{abstract}

Key words: active coating, silver nanoparticle, modified-atmosphere packaging, shelf life of fresh cheese

\section{INTRODUCTION}

As a widely known fresh dairy product, Fior di latte is becoming increasingly popular due to its fresh flavor and very pleasant taste. A fresh cheese, it is considered extremely perishable and very susceptible to microbial spoilage because of its high moisture content (from 55 to $60 \%)$ and high fat content $(>45 \%)$ on a DM basis (Salvadori del Prato, 2001). To preserve the quality, Fior di latte cheese is usually packaged in trays or bags in the presence of brine.

Data in the literature indicate that substitution of brine with a natural hydrogel or a bio-based coating could represent an interesting strategy to allow better preservation of fresh dairy products (Laurienzo et al., 2006, 2008; Del Nobile et al., 2010). Successful results

Received January 10, 2011.

Accepted July 6, 2011.

${ }^{1}$ Corresponding author: ma.delnobile@unifg.it have also been achieved by applying an active coating to the cheese before packaging the product under modified-atmosphere conditions (Conte et al., 2009). Valid synergistic effects between lysozyme/ $\mathrm{Na}_{2}$ EDTA (sodium salt), carried to the product surface by the coating, and modified-atmosphere packaging (MAP) on Fior di latte cheese were demonstrated. Beyond the use of active coating and MAP, Del Nobile et al. (2009) proposed the use of chitosan during the cheese-making process. The addition of chitosan as an antimicrobial compound (Friedman and Juneja, 2010) further enhanced cheese microbial quality, with a consequent prolongation of shelf life. Although the results obtained in this last study are interesting, maintenance of traditional cheese production procedures is a fundamental point for the dairy products; therefore, the use of new coatings and packaging systems aimed at prolonging the shelf life of fresh cheese are generally preferred over innovations applied during milk transformation. For this reason, the present work was aimed at developing a new antimicrobial coating for Fior di latte cheese, to be applied before packaging the product under MAP conditions.

Among compounds with antimicrobial properties, silver nanoparticles (Ag-NP) have been receiving considerable attention because of their attractive physicochemical properties and strong toxicity against a wide range of microorganisms (Sondi and Salopek-Sondi, 2004). Inorganic phyllosilicate clays have been used as support for Ag-NP to generate a new class of antimicrobial systems from which silver ions can be released into media (Incoronato et al., 2010). The presence of inorganic platelets contributes to control the $\mathrm{Ag}^{+}$release and enhance the barrier properties of the composite films. Inactivation of Escherichia coli by Ag-NP has been found to be associated with the concentration of NP (Sondi and Salopek-Sondi, 2004; Pal et al., 2007), bacterial type (Sondi and Salopek-Sondi, 2004; Kim et al., 2007), shape of NP (Kim et al., 2007), presence of Ag ions (Sondi and Salopek-Sondi, 2004), and size of NP (Sondi and Salopek-Sondi, 2004; Baker et al., 2005; Morones et al., 2005; Panacek et al., 2006). Moreover, bacterial growth in the presence of a given concentration of silver has been found to be dependent on the 
initial number of cells (Sondi and Salopek-Sondi, 2004; Pal et al., 2007).

Polymeric systems containing silver represent a viable approach to avoid the direct contact of NP with food. This is particularly important to satisfy the European Union safety regulation that regulates the presence of silver ions in food matrices and limits the amount to $0.05 \mathrm{mg}$ of $\mathrm{Ag} / \mathrm{kg}$, which is not biocidal in food (Fernandez et al., 2009). To the best of our knowledge, very few papers have been reported on the application of $\mathrm{Ag}-\mathrm{NP}$ to food. A valid example was given by An et al. (2008), who applied Ag-NP-based coatings to green asparagus, resulting in an increase in shelf life at $2^{\circ} \mathrm{C}$. Additionally, Fernandez et al. (2009) demonstrated that Ag-NP in absorbent pads could exert beneficial effects on poultry exudates packaged under MAP. Because of the lack of work on Ag-NP applied to dairy foods, the current study was aimed at developing a new coating (nonedible) for Fior di latte cheese, based on alginate loaded with Ag-NP. The work was based on results reported by Incoronato et al. (2010), who studied the antimicrobial properties of silver-montmorillonite nanoparticles $\left(\mathbf{A g}^{+}-\mathbf{M M T}\right)$, produced by allowing silver ions from silver nitrate $\left(\mathrm{AgNO}_{3}\right)$ to replace the exchangeable $\mathrm{Na}^{+}$ counter-ions in the natural sodium montmorillonite. The antimicrobial system was successfully tested on foodborne spoilage microorganisms, suggesting the potential efficacy of $\mathrm{Ag}^{+}$-MMT in real food applications. To this aim, we incorporated different amounts of nanoparticles into an alginate-based solution to coat Fior di latte cheese. After coating, the products were packaged under MAP conditions. During storage at $10^{\circ} \mathrm{C}$ for $1 \mathrm{wk}$, microbiological, physicochemical, and sensory changes were monitored.

\section{MATERIALS AND METHODS}

\section{Preparation of Silver-Montmorillonite Nanoparticles}

Silver MMT nanoparticles were prepared by ion exchange reaction. Before the reaction, $5 \mathrm{~g}$ of Na-MMT was dispersed in $100 \mathrm{~mL}$ of $0.2 \mathrm{M} \mathrm{NaCl}$ for $4 \mathrm{~h}$ while stirring. The solid was then separated by centrifugation (model 4239R; ACL International, Milan, Italy) at $7,826 \times g$ for about $15 \mathrm{~min}$ and then washed 3 times with a small amount of deionized water. The washed Na-MMT was brought in contact with $\mathrm{AgNO}_{3}$ solution at different concentrations. In particular, Na-MMT was dispersed first in a $500 \mathrm{mg} / \mathrm{kg} \mathrm{AgNO}_{3}$ solution at $70^{\circ} \mathrm{C}$ for $3 \mathrm{~h}$ under stirring, covering the top and side of the beaker to prevent exposure to UV light. The solid and liquid parts of the slurry were separated by centrifugation at $7,826 \times g$ for $15 \mathrm{~min}$. Then, the collected solids were brought in contact with 1,000 and $5,000 \mathrm{mg} / \mathrm{kg}$ $\mathrm{AgNO}_{3}$ solutions, following the procedure previously described. Finally, the collected sediment was washed with deionized water 3 times to remove any silver nitrate and allowed to dry overnight in a vacuum oven at $80^{\circ} \mathrm{C}$. Dried samples were ground until a homogeneous powder was obtained. The content of silver in the $\mathrm{Ag}^{+}-$ MMT clays $(0.037 \mathrm{~g} / \mathrm{g})$ was determined by inductively coupled plasma-MS analysis after dissolution in a mixture of $\mathrm{HF}$ and $\mathrm{HNO}_{3}$ (Incoronato et al., 2010).

\section{Coating and Packaging of Fior di Latte Cheese}

Common samples of Fior di latte cheese (50 g) were purchased from a dairy local plant (Posta la Via, Foggia, Italy). The coating solution was prepared by dissolving sodium alginic acid $(8 \% \mathrm{wt} / \mathrm{vol})$ in distilled water. Different amounts $(5,10$, and $15 \mathrm{mg} / \mathrm{mL})$ of $\mathrm{Ag}$-NP were added to the alginate solution and then sonicated in a bath sonicator (model Elmasonic S60H, Elma, Singen, Germany) overnight. Transparent coatings of about 100 $\mu \mathrm{m}$ thick were obtained by immersing cheese samples first in the sodium alginic solution and then in a calcium chloride solution $(5 \% \mathrm{wt} / \mathrm{vol})$ for $1 \mathrm{~min}$. To facilitate the immersion, the Fior di latte sample was held with a toothpick. After the second immersion, the viscous alginic solution around the product instantaneously became a hydrogel that remained close to the Fior di latte surface as a coating. After coating, the toothpick was taken out of the Fior di latte. No hole remained in the product because it healed up after removing the toothpick. Sodium alginic acid and calcium chloride were provided by Sigma-Aldrich Co. (St. Louis, MO). All samples were dried at room temperature for $2 \mathrm{~min}$. Each coated sample was packaged in a commercially available bag with thickness of $95 \mu \mathrm{m}$ (Valco, Bergamo, Italy). The bags, obtained by laminating a nylon layer with a polyolefin layer, had an oxygen transmission rate of $50 \mathrm{~mL} \cdot \mathrm{m}^{-2} \cdot 24 \mathrm{~h}^{-1}$ at $1 \mathrm{~atm}$, measured at $23^{\circ} \mathrm{C}$ and $75 \%$ relative humidity. All bags of coated cheese were sealed under MAP conditions. The gas combination $\left(30 \% \mathrm{CO}_{2}, 5 \% \mathrm{O}_{2}\right.$, and $\left.65 \% \mathrm{~N}_{2}\right)$ was selected according to a previous work with Fior di latte (Conte et al., 2009). In addition to coated samples, 3 packaged cheeses were used as controls: (1) the traditional cheese packaged in presence of brine $(2 \% \mathrm{NaCl}$ solution), (2) the product coated with a free-silver nanoparticles coating, and (3) the product coated with a solution of sodium alginic acid containing $0.25 \mathrm{mg} / \mathrm{mL}$ of lysozyme and $50 \mathrm{~m} M$ EDTA disodium salt ( $\left.\mathrm{Na}_{2} \mathrm{EDTA}\right)$, which represented another example of active coating applied to Fior di latte, as studied in a previous work (Conte et al., 2009). All samples were stored at $10^{\circ} \mathrm{C}$ for $7 \mathrm{~d}$. 
Microbial counts, determinations of $\mathrm{pH}$, headspace gas composition, and sensory evaluations were carried out before packaging and after $1,2,3,4$, and $7 \mathrm{~d}$ of storage.

\section{Microbiological Analyses}

Microbiological analyses for total microbial count, lactic acid bacilli, lactococci, total coliforms, Pseudomonas spp., yeasts, and molds were carried out as reported previously (Conte et al., 2009; Del Nobile et al., 2009; Gammariello et al., 2009). The analyses were repeated twice on 2 different batches of samples.

To quantitatively determine the efficiency of the packaging strategy proposed in this work, a reparameterized version of the Gompertz equation was fitted to the coliform and Pseudomonas data, according to a similar approach used previously (Conte et al., 2009; Del Nobile et al., 2009; Gammariello et al., 2009). The equation allowed calculation of the microbiological acceptability limit (MAL), defined as the time at which microbial loads of selected spoilage microbial groups reached the maximum value permitted. In the specific case, the threshold was $10^{6} \mathrm{cfu} / \mathrm{g}$ for Pseudomonas spp. and $10^{5} \mathrm{cfu} / \mathrm{g}$ for total coliforms (Conte et al., 2009; Del Nobile et al., 2009; Gammariello et al., 2009).

\section{pH Determination}

The $\mathrm{pH}$ of samples was determined by using a $\mathrm{pH}$ meter (Crison, Barcelona, Spain). Each value was the average of 2 measurements, recorded on samples from 2 different batches.

\section{Gas Composition of Headspace}

Contents of $\mathrm{O}_{2}$ and $\mathrm{CO}_{2}$ of the packaged cheeses were measured using a gas meter (PBI Dansensor, Ringsted, Denmark). The volume taken from the package headspace for gas analysis was about $10 \mathrm{~cm}^{3}$. Each bag was used only for a single determination to avoid modifications of headspace composition. Two samples were used at each sampling time.

\section{Sensory Analysis}

Six trained participants evaluated the sensory quality of Fior di latte. The panelists were selected based on their interest in the sensory evaluation of cheese and trained by testing commercial Fior di latte cheese for 3 wk. After training, experienced graders were able to evaluate Fior di latte color, appearance, flavor, and body/texture as the main quality parameters of fresh "pasta filata" cheese (Chen et al., 2009). For the sensory analysis of samples under investigation in this current work, the assessors were simultaneously presented with cubes of randomly coded cheeses. The testing sessions were conducted under normal light conditions. Panelists were asked to evaluate consistency, color, smell, and overall quality of cheeses on a 7-point scale (Corradini and Innocente, 2002). A value of 4 indicated the attribute threshold for cheese general acceptability (Gammariello et al., 2009). Before evaluation, the coating was removed from each cheese sample and immersed in water at room temperature for 10 min, because Fior di latte is generally stored in brine without any coating.

To quantitatively determine the efficacy of the packaging system proposed in this work on the sensory quality, the reparameterized Gompertz equation was also fitted to sensory data. This approach, as used in other work (Conte et al., 2009; Del Nobile et al., 2009; Gammariello et al., 2009), allowed calculation of the sensory acceptability limit (SAL) as the time at which the overall quality of product reached its threshold $($ score $=4)$.

\section{Shelf-Life Calculation}

Because the shelf life of a packaged product is the time at which one of its quality subindices reaches the acceptability threshold (Corbo et al., 2008), the shelf life in the current work was calculated as the lowest value between MAL and SAL, as also reported in other works (Gammariello et al., 2009, 2011).

\section{Statistical Analyses}

The values of MAL, SAL, and shelf life of all investigated samples were compared, respectively, by one-way ANOVA. The Duncan multiple range test with the option of homogeneous groups $(P<0.05)$ was used to determine significance among differences. Statistica 7.1 for Windows (StatSoft Inc., Tulsa, OK) was used for statistical analyses.

\section{RESULTS AND DISCUSSION}

\section{Microbiological Quality}

As assessed in other studies dealing with the deterioration of fresh dairy cheeses, the predominant microflora affecting Fior di latte cheese shelf life is represented by Pseudomonas spp. and coliform bacteria (Gammariello et al., 2008, 2009; Sinigaglia et al., 2008; Conte et al., 2009; Del Nobile et al., 2009). Changes in viable cell concentrations of Pseudomonas spp. are shown in Figure 1a; the curves are the best fit to the experimental data. As can be seen, only the control samples without any active compound went beyond 
the threshold; counts in the other samples remained below $10^{6} \mathrm{cfu} / \mathrm{g}$ during the entire observation period. Consequently, the MAL values for all the active coated samples exceeded the monitored $7 \mathrm{~d}$ (Table 1). Data demonstrated that MAP combined with the active coating could enhance microbial stability by inhibiting the proliferation of Pseudomonas spp. The 2 control samples recorded the worst result, with microbial quality acceptable for about $3 \mathrm{~d}$, whereas samples with $\mathrm{Ag}-\mathrm{NP}$ and lysozyme/ $\mathrm{Na}_{2}$ EDTA-coated samples recorded MAL values greater than 1 wk. To highlight the differences between these active coated samples, the maximum cell load attained on d 7 of storage was taken into account (Table 2). The 2 controls showed the highest microbial load, the samples with lysozyme/ $\mathrm{Na}_{2}$ EDTA coating recorded a microbial concentration equal to $5.16 \log \mathrm{cfu} / \mathrm{g}$, whereas samples coated with Ag-MMT attained a microbial concentration from 4.48 to $3.26 \log \mathrm{cfu} / \mathrm{g}$, depending on the amount of Ag-MMT incorporated. The effectiveness of lysozyme/ $\mathrm{Na}_{2} \mathrm{EDTA}$ and MAP on Pseudomonas spp., as demonstrated by Conte et al. (2009) and Del Nobile et al. (2009), was confirmed in the current work; in addition, the new inorganic antimicrobial compound embedded into the bio-based coating seemed to be a valid alternative solution to control Pseudomonas spp. growth.

Figure 1b shows the evolution of total coliforms over storage time for the 3 control Fior di latte samples. Although microbial counts in the control samples slightly increased, viable cell concentrations in all the Ag-MMT-coated samples were undetectable along the entire observation period, resulting in a MAL ${ }^{\text {Coliforms }}$ value greater than $7 \mathrm{~d}$. As above, the maximum cell load attained at the end of the observation period was estimated for the different packaged cheeses (Table 2). Data listed in Table 2 indicate that the nanocomposite systems are more successful in controlling proliferation of coliforms than the other tested packaging systems.

As far as typical dairy microorganisms are concerned, Figure 2 illustrates data for lactic acid bacteria for all Fior di latte cheese samples. As shown, the cell load of the flora type was not affected by the packaging system, suggesting that the active coating, as well as MAP conditions, did not influence the growth of typical dairy microorganisms (Eliot et al., 1998; Del Nobile et al., 2009, 2010).

No molds were detected on samples during the storage period. With regard to yeasts, the load in the coated samples remained low and constant over time, whereas in the control samples the load increased from $10^{2}$ to about $10^{3} \mathrm{cfu} / \mathrm{g}$ in the stationary phase (data not shown).

The total microbial count was similar in all samples (data not shown), with a slightly lower microbial load
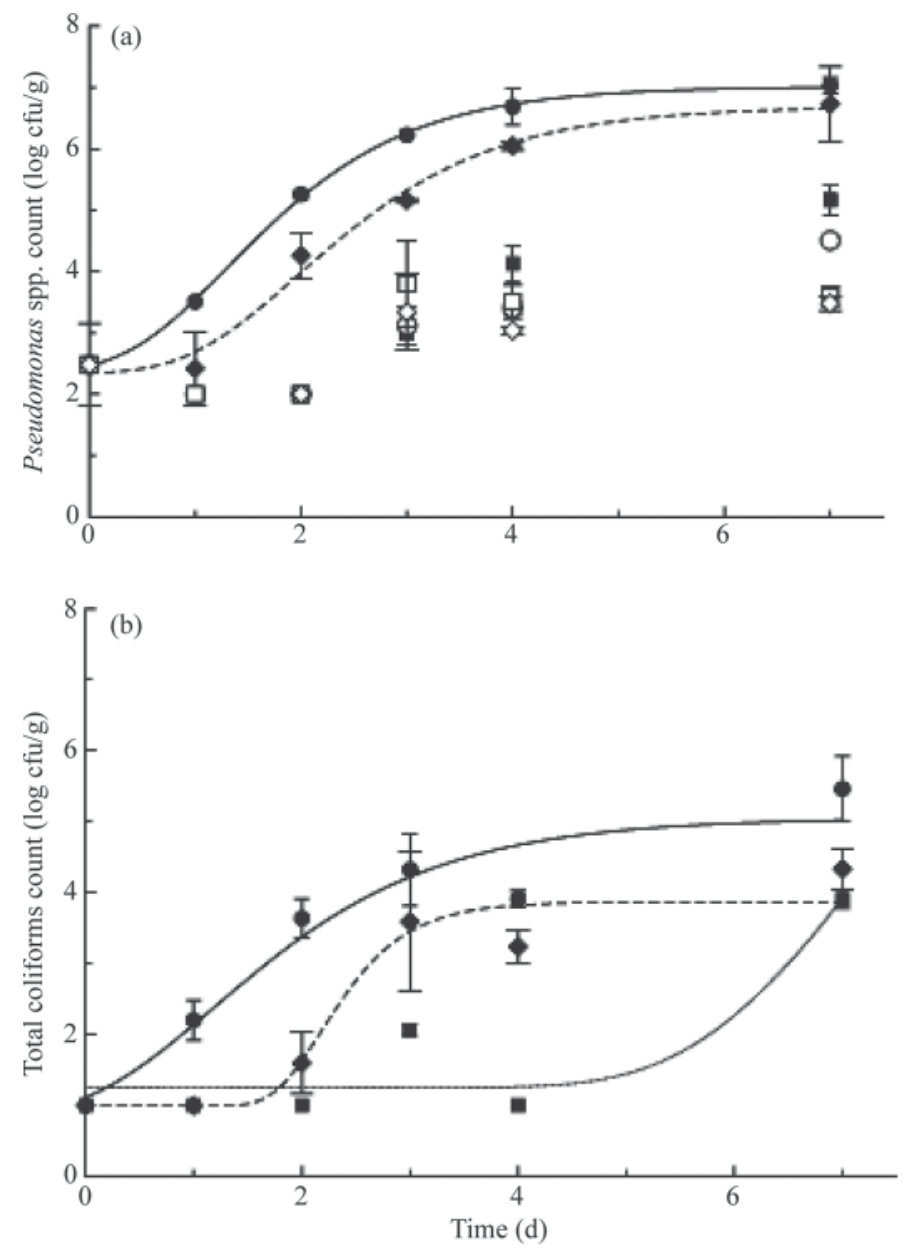

Figure 1. Evolution of (a) Pseudomonas spp. and (b) coliform count in Fior di latte cheese during the 7-d storage period. Control $(\bullet)$ $=$ stored in brine; Coa-MAP $(\bullet)=$ coated with alginate, stored under modified-atmosphere packaging (MAP); Lys-Coa-MAP $(\mathbf{\square})=$ coated with alginate loaded with lysozyme and EDTA, stored under MAP; Ag5-Coa-MAP $(O)=$ coated with alginate loaded with $5 \mathrm{mg} / \mathrm{mL}$ silver nanoparticles, stored under MAP; Ag10-Coa-MAP $(\square)=$ coated with alginate loaded with $10 \mathrm{mg} / \mathrm{mL}$ silver nanoparticles, stored under MAP; Ag15-Coa-MAP $(\diamond)=$ coated with alginate loaded with $15 \mathrm{mg} /$ $\mathrm{mL}$ silver nanoparticles, stored under MAP. No growth of coliforms was observed for Ag5-Coa-MAP, Ag10-Coa-MAP, and Ag15-CoaMAP samples. The curves are the best fit to the experimental data.

in the silver-coated samples than in the other analyzed cheese samples.

\section{Physicochemical Characterization}

With regard to $\mathrm{pH}$ data (data not shown), a similar trend was recorded for all samples. The $\mathrm{pH}$ value remained almost constant over the monitored 7 -d period.

Figure 3 shows the evolution of the $\mathrm{O}_{2}$ and $\mathrm{CO}_{2}$ in the package headspace of bags sealed under MAP. Similar values of gas concentration were recorded for all coated samples. In particular, $\mathrm{O}_{2}$ content remained constant around 5\%, except for cheese coated with the 
Table 1. Shelf life (d) of Fior di latte samples evaluated as the lowest value between microbial acceptability limit (MAL) and sensorial acceptability limit (SAL) ${ }^{1}$

\begin{tabular}{lcccc}
\hline Sample $^{2}$ & MAL $^{\text {Pseudomonas }}$ & MAL $^{\text {Coliforms }}$ & SAL & Shelf life \\
\hline Control & $2.68 \pm 0.05^{\mathrm{a}}$ & $>7$ & $6.72 \pm 0.57^{\mathrm{a}}$ & $2.68 \pm 0.05^{\mathrm{a}}$ \\
Coa-MAP & $3.82 \pm 0.36^{\mathrm{b}}$ & $>7$ & $4.91 \pm 2.01^{\mathrm{a}}$ & $3.82 \pm 0.36^{\mathrm{b}}$ \\
Lys-Coa-MAP & $>7$ & $>7$ & $2.59 \pm 0.12^{\mathrm{b}}$ & $2.59 \pm 0.12^{\mathrm{a}}$ \\
Ag5-Coa-MAP & $>7$ & $>7$ & $5.58 \pm 2.03^{\mathrm{a}}$ & $5.58 \pm 2.03^{\mathrm{bc}}$ \\
Ag10-Coa-MAP & $>7$ & $>7$ & $4.98 \pm 0.48^{\mathrm{a}}$ & $4.98 \pm 0.48^{\mathrm{c}}$ \\
Ag15-Coa-MAP & $>7$ & $>7$ & $5.05 \pm 0.54^{\mathrm{a}}$ & $5.05 \pm 0.54^{\mathrm{c}}$ \\
\hline
\end{tabular}

${ }^{\mathrm{a}-\mathrm{C}}$ Data in column with different letters are significantly different $(P<0.05)$.

${ }^{1}$ Values are means $\pm \mathrm{SE} ; \mathrm{n}=2$.

${ }^{2}$ Control $=$ stored in brine; Coa-MAP $=$ coated with alginate, stored under modified-atmosphere packaging (MAP); Lys-Coa-MAP = coated with alginate loaded with lysozyme and EDTA, stored under MAP; Ag5-CoaMAP = coated with alginate loaded with $5 \mathrm{mg} / \mathrm{mL}$ silver nanoparticles, stored under MAP; Ag10-Coa-MAP = coated with alginate loaded with $10 \mathrm{mg} / \mathrm{mL}$ silver nanoparticles, stored under MAP; Ag15-Coa-MAP = coated with alginate loaded with $15 \mathrm{mg} / \mathrm{mL}$ silver nanoparticles, stored under MAP.

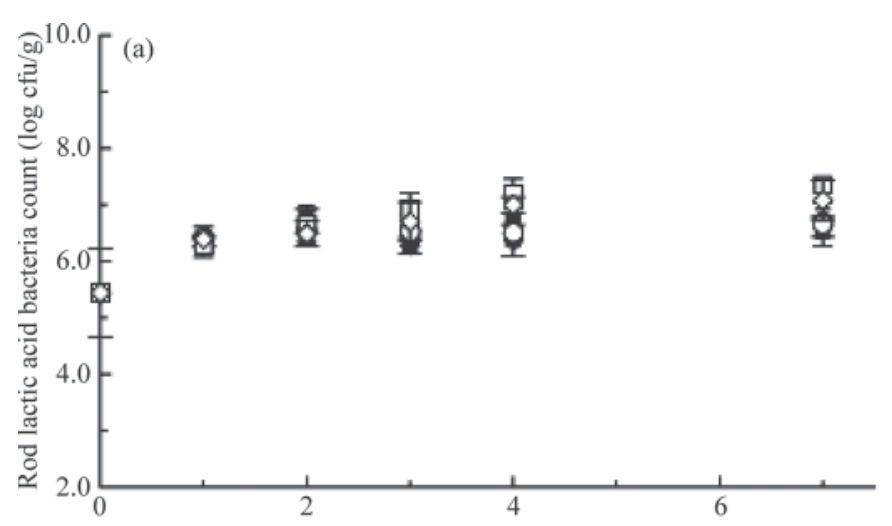

free-compound coating, in which $\mathrm{O}_{2}$ decreased at the end of the storage; in contrast, the $\mathrm{CO}_{2}$ decreased from 30 to $25 \%$ in all samples. This change in gas composition was relatively small, suggesting that the initial MAP conditions lasted throughout the storage time. Most probably, this can be ascribed to the high barrier properties of the packaging film that limited mass exchange through the polymeric package (Del Nobile et al., 2009).

\section{Sensory Quality}

Figure 4 gives overall quality plotted as a function of storage time for all samples. The curves shown in the figure were obtained by the fitting procedure; the values of SAL are also listed in Table 1. A steady decrease in overall quality could be seen throughout storage for all samples. Cheeses showed similar SAL values, being acceptable for about 5 to $6 \mathrm{~d}$, except for the coated cheese

Table 2. Pseudomonas and coliform maximum cell load (log cfu/g) of Fior di latte cheese attained on d 7 of storage ${ }^{1}$

\begin{tabular}{lcc}
\hline Sample $^{2}$ & Pseudomonas spp. & Coliforms \\
\hline Control & $7.00 \pm 0.05^{\mathrm{d}}$ & $5.02 \pm 0.46^{\mathrm{b}}$ \\
Coa-MAP & $6.65 \pm 0.30^{\mathrm{d}}$ & $3.87 \pm 0.42^{\mathrm{ab}}$ \\
Lys-Coa-MAP & $5.16 \pm 0.29^{\mathrm{c}}$ & $2.61 \pm 1.21^{\mathrm{a}}$ \\
Ag5-Coa-MAP & $4.48 \pm 0.47^{\mathrm{b}}$ & $\mathrm{ND}^{3}$ \\
Ag10-Coa-MAP & $3.52 \pm 0.37^{\mathrm{a}}$ & $\mathrm{ND}$ \\
Ag15-Coa-MAP & $3.26 \pm 0.39^{\mathrm{a}}$ & $\mathrm{ND}$ \\
\hline
\end{tabular}

${ }^{\mathrm{a}-\mathrm{d}}$ Data in column with different letters are significantly different $(P$ $<0.05)$.

${ }^{1}$ Values are means $\pm \mathrm{SE} ; \mathrm{n}=2$.

Figure 2. Evolution of (a) rod and (b) coccus-shaped lactic acid bacteria count in Fior di latte cheese during the storage period. Control $(\bullet)=$ stored in brine; Coa-MAP $(\bullet)=$ coated with alginate, stored under modified-atmosphere packaging (MAP); Lys-Coa-MAP

$(\boldsymbol{\square})=$ coated with alginate loaded with lysozyme and EDTA, stored under MAP; Ag5-Coa-MAP $(O)=$ coated with alginate loaded with 5 $\mathrm{mg} / \mathrm{mL}$ silver nanoparticles, stored under MAP; Ag10-Coa-MAP ( $\square$ ) $=$ coated with alginate loaded with $10 \mathrm{mg} / \mathrm{mL}$ silver nanoparticles, stored under MAP; $\operatorname{Ag} 15$-Coa-MAP $(\diamond)=$ coated with alginate loaded with $15 \mathrm{mg} / \mathrm{mL}$ silver nanoparticles, stored under MAP.

${ }^{2} \mathrm{Control}=$ stored in brine; Coa-MAP $=$ coated with alginate, stored under modified-atmosphere packaging (MAP); Lys-Coa-MAP = coated with alginate loaded with lysozyme and EDTA, stored under MAP Ag5-Coa-MAP = coated with alginate loaded with $5 \mathrm{mg} / \mathrm{mL}$ silver nanoparticles, stored under MAP; Ag10-Coa-MAP = coated with alginate loaded with $10 \mathrm{mg} / \mathrm{mL}$ silver nanoparticles, stored under MAP; Ag15-Coa-MAP = coated with alginate loaded with $15 \mathrm{mg} / \mathrm{mL}$ silver nanoparticles, stored under MAP.

${ }^{3} \mathrm{ND}=$ nondetectable. 

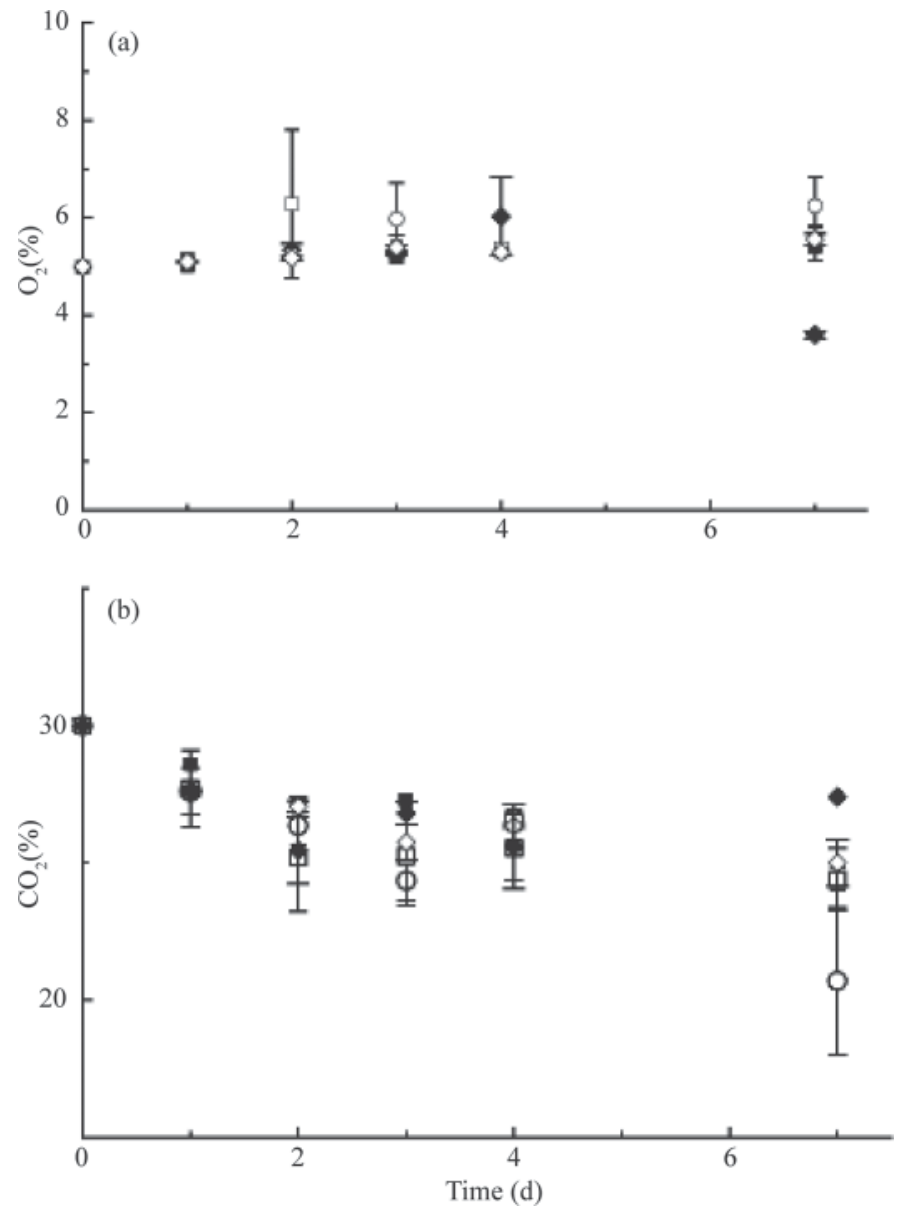

Figure 3. Evolution of (a) oxygen and (b) carbon dioxide in hermetically sealed bags of Fior di latte cheese. Coa-MAP $(\bullet)=$ coated with alginate, stored under modified-atmosphere packaging (MAP); Lys-Coa-MAP $(\boldsymbol{\square})$ = coated with alginate loaded with lysozyme and EDTA, stored under MAP; Ag5-Coa-MAP $(O)=$ coated with alginate loaded with $5 \mathrm{mg} / \mathrm{mL}$ silver nanoparticles, stored under MAP; Ag10-Coa-MAP $(\square)=$ coated with alginate loaded with $10 \mathrm{mg} / \mathrm{mL}$ silver nanoparticles, stored under MAP; Ag15-Coa-MAP $(\diamond)=$ coated with alginate loaded with $15 \mathrm{mg} / \mathrm{mL}$ silver nanoparticles, stored under MAP.

containing lysozyme that became unacceptable after less than $3 \mathrm{~d}$. The findings for samples with lysozyme/ $\mathrm{Na}_{2}$ EDTA confirmed previous results. In particular, the enzyme combined with the sodium salt influenced product consistency, which compromised its acceptability after a few days of storage (Conte et al., 2009; Del Nobile et al., 2009). On the contrary, Fior di latte with an Ag-MMT coating had better overall quality for the same period compared with the uncoated cheese, thus demonstrating the efficacy of this system in preserving the product without compromising sensory attributes.

\section{Shelf-Life Evaluation}

Fior di latte shelf life values, calculated as the minimum of MAL and SAL, are listed in Table 1 for

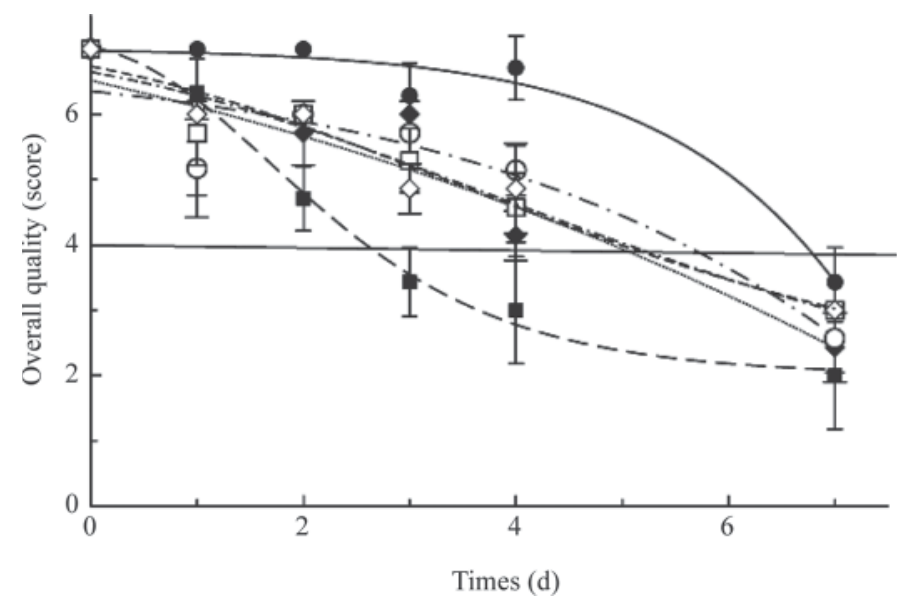

Figure 4. Overall quality of Fior di latte cheese during the storage period. Control $(\bullet)=$ stored in brine; Coa-MAP $(\bullet)=$ coated with alginate, stored under modified-atmosphere packaging (MAP); Lys-Coa-MAP $(\boldsymbol{\square})=$ coated with alginate loaded with lysozyme and EDTA, stored under MAP; Ag5-Coa-MAP $(O)=$ coated with alginate loaded with $5 \mathrm{mg} / \mathrm{mL}$ silver nanoparticles, stored under MAP; Ag10-Coa-MAP $(\square)=$ coated with alginate loaded with $10 \mathrm{mg} / \mathrm{mL}$ silver nanoparticles, stored under MAP; Ag15-Coa-MAP $(\diamond)=$ coated with alginate loaded with $15 \mathrm{mg} / \mathrm{mL}$ silver nanoparticles, stored under MAP. The curves are the best fit to experimental data.

each sample tested in this study. As can be seen, a significant prolongation of shelf life was recorded for samples packaged with the active coating based on Ag-MMT compared with other samples. From the obtained data, microbial quality limited the shelf life of control cheese packaged without any active compound, whereas sensory quality represented the limiting factor for all coated cheese samples. However, substantial differences in shelf life were recorded between the various coated products, because the enzyme affects Fior di latte consistency. Data confirmed that a simple coating plus MAP is not sufficient to enhance product quality. Lysozyme/ $\mathrm{Na}_{2}$ EDTA with MAP can prolong microbial stability (Conte et al., 2009; Del Nobile et al., 2009), whereas the developed nanocomposite system prevented microbial growth without affecting sensory properties, thus promoting prolongation of Fior di latte shelf life.

\section{CONCLUSIONS}

Silver nanoparticles incorporated in a bio-based coating, in combination with MAP, were used to prolong the shelf life of Fior di latte cheese. Main quality attributes were monitored for about $7 \mathrm{~d}$ to determine the decline in product quality during storage. Fior di latte packaged in brine, coated with a simple coating without any active compound, or treated with a coating containing lysozyme/ $\mathrm{Na}_{2}$ EDTA showed a shelf life limited to about $3 \mathrm{~d}$. In contrast, the developed nanocomposite system allowed a significant prolongation of 
shelf life to more than $5 \mathrm{~d}$, irrespective of the amount of Ag-MMT in the coating. This strategy for shelf-life prolongation could be adopted by the industrial sector because of its simple application. Nevertheless, it must be noted that the developed coating containing nanoparticles needs to be removed before eating Fior di latte and that extensive research is essential to assess the safety concerns related to silver that migrates to the food and ensure compliance with the European Union regulation.

\section{ACKNOWLEDGMENTS}

This work was financially supported by the Ministero dell'Economia e delle Finanze, Ministero dell'Istruzione, dell'Università e della Ricerca Scientifica e Tecnologica by the project Legge 297/99 Art. 12 (Tecnologie per il Packaging Bioattivo di Prodotti Lattiero Caseari Freschi Pugliesi; DM 29040).

\section{REFERENCES}

An, J., M. Zhang, S. Wang, and J. Tang. 2008. Physical, chemical and microbiological changes in stored green asparagus spears as affected by coating of silver nanoparticles-PVP. Lebensm. Wiss. Technol. 41:1100-1107.

Baker, C., A. Pradhan, L. Pakstis, D. J. Pochan, and S. Ismat Shah. 2005. Synthesis and antimicrobial properties of silver nanoparticles. J. Nanosci. Nanotechnol. 5:244-249.

Chen, C., D. Wolle, and D. Sommer. 2009. Mozzarella. Pages 468-469 in The Sensory Evaluation of Dairy Products. 2nd ed. S. Clark, M. Costello, M. Drake, and F. Bodyfelt, ed. Springer Science+Business Media, Dordrecht, the Netherlands.

Conte, A., D. Gammariello, S. Di Giulio, M. Attanasio, and M. A. Del Nobile. 2009. Active coating and modified-atmosphere packaging to extend the shelf life of Fior di latte cheese. J. Dairy Sci. 92:887-894.

Corbo, M. R., B. Speranza, A. Filippone, S. Granatiero, A. Conte, M. Sinigaglia, and M. A. Del Nobile. 2008. Study on the synergic effect of natural compounds on the microbial quality decay of packed fish hamburger. Int. J. Food Microbiol. 127:261-267.

Corradini, C., and N. Innocente. 2002. Parametri chemiometrici e descrittori sensoriali del Montasio DOP. Notiziario Ersa 4/2002:4345.

Del Nobile, M. A., D. Gammariello, A. Conte, and M. Attanasio. 2009 A combination of chitosan, coating and modified atmosphere packaging for prolonging Fior di latte cheese shelf life. Carbohydr. Polym. 78:151-156.

Del Nobile, M. A., D. Gammariello, S. Di Giulio, and A. Conte. 2010. Active coating to prolong the shelf life of Fior di latte cheese. J. Dairy Res. 77:50-55.
Eliot, S. C., J. C. Vuillemard, and J. P. Emond. 1998. Stability of shredded Mozzarella cheese under modified atmospheres. J. Food Sci. $63: 1075-1080$.

Fernandez, A., E. Soriano, G. Lopez-Carballo, P. Picouet, E. Lloret, R. Gavara, and P. Hernandez-Munoz. 2009. Preservation of aseptic conditions in absorbent pads by using silver nanotechnology. Food Res. Int. 42:1105-1112.

Friedman, M., and V. K. Juneja. 2010. Review of antimicrobial and antioxidative activities of chitosan in food. J. Food Prot. $73: 1737-1761$

Gammariello, D., A. Conte, M. Attanasio, and M. A. Del Nobile. 2011. A study on the synergy of modified atmosphere packaging and chitosan on stracciatella shelf life. J. Food Process Eng. doi:10.1111/ j.1745-4530.2009.00537.x.

Gammariello, D., A. Conte, S. Di Giulio, M. Attanasio, and M. A. Del Nobile. 2009. Shelf life of Stracciatella cheese under modifiedatmosphere packaging. J. Dairy Sci. 92:483-490.

Gammariello, D., S. Di Giulio, A. Conte, and M. A. Del Nobile. 2008. Effects of natural compounds on microbial safety and sensory quality of Fior di latte cheese, a typical Italian cheese. J. Dairy Sci. 91:4138-4146.

Incoronato, A. L., G. G. Buonocore, A. Conte, M. Lavorgna, and M. A. Del Nobile. 2010. Antimicrobial activity of silver/montmorillonite nanoparticles embedded into bio-based polymer matrices. J. Food Prot. 73:2256-2262.

Kim, J. S., E. Kuk, K. N. Yu, J. H. Kim, S. J. Park, H. J. Lee, S. H. Kim, Y. K. Park, Y. H. Park, C. Y. Hwang, Y. K. Kim, Y. S. Lee, D. H. Jeong, and M. H. Cho. 2007. Antimicrobial effects of silver nanoparticles. Nanomedicine 3:95-101.

Laurienzo, P., M. Malinconico, G. Mazzarella, F. Petitto, N. Piciocchi, R. Stefanile, and M. G. Volpe. 2008. Water buffalo mozzarella cheese stored in polysaccharide-based gels: Correlation between prolongation of the shelf life and physicochemical parameters. J. Dairy Sci. 91:1317-1324.

Laurienzo, P., M. Malinconico, R. Pizzano, C. Manzo, N. Piciocchi, A. Sorrentino, and M. G. Volpe. 2006. Natural polysaccharide-based gels for dairy food preservation. J. Dairy Sci. 89:2856-2864.

Morones, J. R., J. L. Elechiguerra, A. Camacho, K. Holt, J. B. Kouri, J. T. Ramirez, and M. J. Yacaman. 2005. The bactericidal effect of silver nanoparticles. Nanotechnology 16:2346-2353.

Pal, S., Y. K. Tak, and J. M. Song. 2007. Does the antibacterial activity of silver nanoparticles depend on the shape of the nanoparticle? A study of the Gram-negative bacterium Escherichia coli. Appl. Environ. Microbiol. 73:1712-1720.

Panacek, A. L. Kvitek, R. Prucek, M. Kolar, R. Vecerova, N. Pizurova, V. K. Sharma, T. Nevecna, and R. Zboril. 2006. Silver colloid nanoparticles: Synthesis, characterization, and their antibacterial activity. J. Phys. Chem. B 110:16248-16253.

Salvadori del Prato, O. 2001. Trattato di Tecnologia Casearia. Calderoni Ed. Agricole, Bologna, Italy.

Sinigaglia, M., A. Bevilacqua, M. R. Corbo, S. Pati, and M. A. Del Nobile. 2008. Use of active compounds for prolonging the shelf life of Mozzarella cheese. Int. Dairy J. 18:624-630.

Sondi, I., and B. Salopek-Sondi. 2004. Silver nanoparticles as antimicrobial agent: A case study of $E$. coli as a model for gram-negative bacteria. J. Colloid Interface. Sci. 275:177-182. 